Pesq. Vet. Bras. 38(5):967-972, maio 2018

\title{
Improved method for diagnosis of Nerium oleander poisoning in necropsy tissues ${ }^{1}$
}

\author{
Ana F.M. Botelho², Fabiano A.S. Oliveira ${ }^{3}$, Aparecida T.L. Fiúza², Heloísa P. Pedroza², \\ Stephanie E.M.T. Branco ${ }^{2}$, Felipe Pierezan², Marília M. Melo² \\ and Benito Soto-Blanco ${ }^{2 *}$
}

\begin{abstract}
Botelho A.F.M., Oliveira F.A.S., Fiúza A.T.L., Pedroza H.P., Branco S.E.M.T., Pierezan F., Melo M.M. \& Soto-Blanco B. 2018. Improved method for diagnosis of Nerium oleander poisoning in necropsy tissues. Pesquisa Veterinária Brasileira 38(5):967-972. Departamento de Clínica e Cirurgia Veterinárias, Escola de Veterinária, Universidade Federal de Minas Gerais, Avenida Antônio Carlos 6627, Belo Horizonte, MG 30123-970, Brazil. E-mail: benito.blanco@pq.cnpq.br

Nerium oleander is an ornamental cardiotoxic plant found in tropical and subtropical areas of the World. Its toxicity is related to the content of cardioactive glycosides, mainly oleandrin, found throughout the plant. The present study aimed to describe a new and improved method for oleandrin detection in tissue samples. The determination of oleandrin was made after extraction with a modified QuEChERS technique and measurement by UFLC-MS/MS. A total of 36 guinea pigs (Cavia porcellus) were distributed into 3 groups $(\mathrm{n}=12)$ : control group that received only water orally $(\mathrm{CON})$, and two treated groups that received hydroalcoholic oleander extract at doses of $150 \mathrm{mg} \cdot \mathrm{kg}^{-1}$ (OLE 150) and 300 mg. $\mathrm{kg}^{-1}$ (OLE 300) in single oral dose. After three hours, fragments of heart, kidneys, liver and brain were collected for determination of oleandrin levels. The extraction and chromatographic procedures were effective for oleandrin detection and quantification in tissues, with retention time of $1.2 \mathrm{~min}$ and detection limit of $0.001 \mu \mathrm{g} \mathrm{g}^{-1}$. The chromatographic analysis of treated guinea pigs indicated that oleandrin is distributed equally among the analyzed tissues. The developed methodology is a reliable, effective and rapid form of diagnosis of $N$. oleander poisoning based on necropsy tissue samples.
\end{abstract}

INDEX TERMS: Oleander, Nerium oleander, cardenolides, diagnostic testing, liquid chromatography, mass spectrometry, guinea pigs, toxicoses.

RESUMO.- [Método aprimorado para diagnóstico da intoxicação por Nerium oleander em tecidos de necropsia.] Nerium oleander é uma planta cardiotóxica ornamental encontrada em áreas tropicais e subtropicais do mundo. Sua toxicidade é relacionada á presença de glicosídeos cardioativos, principalmente a oleandrina, encontrada em toda a planta. 0 presente estudo objetiva descrever um novo e aprimorado método para detecção da oleandrina em amostras

\footnotetext{
${ }^{1}$ Received on February 17, 2017.

Accepted for publication on April 27, 2017.

${ }^{2}$ Departamento de Clínica e Cirurgia Veterinárias, Escola de Veterinária, Universidade Federal de Minas Gerais (UFMG), Avenida Antônio Carlos 6627, Belo Horizonte, MG 30123-970, Brazil. *Corresponding author: benito.blanco@pq.cnpq.br

${ }^{3}$ Laboratório Nacional Agropecuário (Lanagro/MG), Ministério da Agricultura, Pecuária e Abastecimento, Avenida Rômulo Joviano s/n, Cx. Postal 35, Pedro Leopoldo, MG 33600-000, Brazil.
}

de tecido. A determinação da oleandrina foi feita após extração utilizando técnica modificada de QuEChERS e mensuração por UFLC-MS/MS. Um total de 36 cobaios (Cavia porcellus) foi distribuído em três grupos ( $n=12)$ : grupo controle que recebeu apenas água por via oral (CON), e dois grupos tratados que receberam extrato hidroalcóolico de oleander nas doses de $150 \mathrm{mg} . \mathrm{kg}^{-1}$ (OLE 150) e 300mg.kg-1 (OLE 300) em uma única dose oral. Após três horas, fragmentos do coração, rins, fígado e cérebro foram coletados para determinação dos níveis de oleandrina. A extração e procedimentos cromatográficos foram eficientes na detecção e quantificação da oleandrina nos tecidos, com tempo de retenção de 1,2min e limite de detecção de $0,001 \mu \mathrm{g} \mathrm{g}^{-1}$. A análise cromatográfica dos animais tratados indicou que a oleandrina é distribuída de forma equalizada pelos tecidos analisados. A metodologia desenvolvida representa uma forma de diagnóstica segura, 
efetiva e rápida da intoxicação por $N$. oleander a partir de amostras de tecidos de necropsia.

TERMOS DE INDEXAÇÃO: Oleander, Nerium olender, cardenolídeos, teste diagnóstico, cromatografia líquida, espectrometria de massa, cobaias, toxicoses.

\section{INTRODUCTION}

Nerium oleander L. is an ornamental plant that belongs to the family Apocynaceae, native in Mediterranean regions of Europe and Asia and cultivated in tropical and subtropical areas of the world. All parts of the plant are poisonous, including flowers, fruits, leaves and roots (Langford \& Boor 1996). Its ingestion can lead to acute heart lesions and death in humans and animals (Bandara et al. 2010, Caloni et al. 2012). Poisoning reports have been described in South and North America (Dorsey 1962), Europe (Caloni et al. 2012), Australia (Hughes et al. 2002) and Asia (Khan et al. 2010) and most cases are caused by accidental ingestion, attempted suicide and phytotherapic use of $N$. oleander (Bandara et al. 2010, Dorsey 1962). Veterinary reports are associated with times of drought, lack of forage and curiosity of the animals (Langford \& Boor 1996, Soto-Blanco et al. 2006, Caloni et al. 2012) and have been reported in dogs (Caloni et al. 2012), cattle (Soto Blanco et al. 2006), horses (Hughes et al. 2002), sheep (Barbosa et al. 2008), and birds (Alfonso et al. 1994).

$N$. oleander toxicity is attributed to cardiac glycosides, including oleandrin, rosagenin, folinerin, nerlin and digitoxigenin (Begum et al. 1999).

These substances are structurally similar to digoxin and can potentially inhibit the $\mathrm{Na}+/ \mathrm{K}+$ pump of the heart and cause severe clinical signs that may include nausea, vomiting, abdominal pain, diarrhea, drowsiness, paresthesia, dyspnea and cardiac arrhythmias (Soto-Blanco et al. 2006, Bandara et al. 2010).

Diagnosis of the poisoning is based on clinical signs, medical record, description of the plant and necropsy findings that are usually similar to other intoxications. Definitive diagnosis is only provided by laboratory testing (Bandara et al. 2010). Current available techniques for the detection of $N$. oleander toxic components include digoxin immunoassay, liquid chromatography, HPLC and spectrophotometric assay (Karawya et al. 1973, Dasgupta \& Datta 2004, Tor et al. 2005).

The first description of cardiac glycoside identification was a colorimetric method based on Baljet's reagent (picric acid in alkaline medium) and produced initial data on N. oleander glycoside content (Karawya et al. 1973). Studies considering molecular similarities between digoxin and oleandrin suggested that radioimmunoassays could be helpful in diagnosing the poisoning. Several reports correlated serum levels of digoxin and oleandrin for presumptive diagnosis of $N$. oleander poisoning (Shumaik et al. 1988, Dasgupta et al. 2011), although important discrepancies between concentrations can be found (Blum \& Rieders 1987).

Thin layer chromatography, fluorescence spectrometry, and immunoassays were also studied and determined to be insufficiently sensitive or specific to detect and quantify oleandrin in biological tissues (Blum \& Rieders 1987). Especially in forensic situations, undeniable identification of oleandrin is required and liquid chromatography coupled to mass spectrometry (LC-MS) is the most recommend method (Tor et al. 2005).

In these cases LC-MS is a rapid and precise methodology that confirms $N$. oleander exposure through its main component oleandrin (Tor et al. 2005). LC-MS methodologies require small volume of samples and solvents (Oliveira et al. 2014). Considering the significance of $N$. oleander poisonings, its severe toxicity and the importance of quick diagnosis, this study aimed to develop a simple, rapid and precise method for tissue extraction and quantification of oleandrin in necropsy samples.

The method is based on the QuEChERS (Quick, Easy, Cheap, Effective, Rugged and Safe) extraction, originally developed as a field of application for residue analysis of pesticides (Anastassiades et al. 2003). In recent years, however, the method has also been applied, with satisfactory results, to the analysis of other contaminants and residues, such as mycotoxins, veterinary drugs, steroids and plant toxins, in different matrices, such as milk, animal tissues, beverages, honey, egg and animal feed (Mol et al. 2008, Klinsunthorn et al. 2011, Tamura et al. 2011). Modified extraction technique and ultra-fast liquid chromatography/tandem mass spectrometry (UFLC-MS/MS) analysis, provides specific and faster diagnosis for $N$. oleander poisoning.

\section{MATERIALS AND METHODS}

Animals and groups. The research project was approved by the Ethical Committee for Animal Experimentation of Universidade Federal de Minas Gerais (CEUA/UFMG) under protocol number 216/2014. Nerium oleander L. (family Apocynaceae) leaves were harvested from a white flowered plant in Belo Horizonte/MG, Brazil. A voucher specimen was deposited in the BHCB Herbarium at UFMG, Belo Horizonte/MG, Brazil, under number BHCB 182685. Fresh leaves were cleaned and dried in a heater at $60^{\circ} \mathrm{C}$ for 48 hours. Leaves were grinded and extracted with hydroalcoholic (1:1) solution in ultrasonic bath for 20min (Karawya et al. 1973, Calderón-Montaño et al. 2013). Ethanol was eliminated with rotating evaporator and extract was diluted with water.

A total of 36 adult male guinea pigs, mean weight $700 \mathrm{~g}(600-900 \mathrm{~g})$, were kept in cages maintained under appropriate conditions in the Laboratory of Animal Experimentation, Veterinary School, UFMG, and received commercial chow and water ad libitum. They were randomly distributed into three equal groups $(n=12)$ : CON control group that only received water, OLE 150 that received $150 \mathrm{mg} . \mathrm{kg}^{-1}$ of $N$. oleander extract and OLE 300 that received the same extract at $300 \mathrm{mg} . \mathrm{kg}^{-1}$. These administrations were performed once via oral gavage. They were clinically monitored and euthanized after 3 hours with $150 \mathrm{mg} \cdot \mathrm{kg}^{-1}$ of thiopental, by intraperitoneal injection.

Tissue extraction. Immediately after necropsy exam was conducted, samples from the heart, liver, kidneys and cerebral cortex were collect, weighed and stored frozen in $-20^{\circ} \mathrm{C}$. Samples were homogenized for extraction with adapted QuEChERS methodology (Oliveira et al. 2014).

Ultrapure water, for preparation of the aqueous mobile phase, was obtained via a water purification system (Direct 3-Q UV, Millipore, Molsheim, France). Oleandrin standard ( $>95 \%$ purity; Sigma-Aldrich Chemical Co., St Louis, MO, USA) was used for control analysis. Tissue samples from control group, including brain, liver, kidney and heart were used as blank matrix.

Samples of $5 \mathrm{~g}$ from each tissue (blank and sample) were weighed and $5 \mathrm{~mL}$ of water added for homogenization in vortex mixer for $1 \mathrm{~min}$. 
Extraction phase was conducted with $7 \mathrm{~mL}$ of $\mathrm{MeCN}$ (acetonitrile MS grade, Tedia, Fairfield, $\mathrm{OH}$, USA), $3 \mathrm{~mL}$ of ethyl acetate PA (Tedia, Fairfield, $\mathrm{OH}, \mathrm{USA}$ ), $4 \mathrm{~g}$ of $\mathrm{MgSO}_{4}$ (magnesium sulphate; Sigma-Aldrich Chemical Co., St Louis, MO, USA) and $1 \mathrm{~g}$ of $\mathrm{CH}_{3} \mathrm{COONa}$ (anhydrous sodium acetate, purity $\geq 98 \%$; Vetec, Rio de Janeiro, Brazil). Samples were centrifuged in 4000rpm for $11 \mathrm{~min}$ and frozen overnight followed by another centrifugal process in 4000rpm for $5 \mathrm{~min}$. The supernatant $(1.0 \mathrm{~mL})$ was transferred to a $1.5 \mathrm{~mL}$ centrifuge microtube (Eppendorf, Hamburg, German) containing 150mg of $\mathrm{MgSO}_{4}, 30 \mathrm{mg}$ of PSA (primary secondary amine; Varian, Harbor City, CA, USA) and 30mg of C18 (Sigma-Aldrich Chemical Co., St Louis, MO, USA). Samples were agitated for $1 \mathrm{~min}$ in vortex mixer and centrifuge in $9000 \mathrm{rpm}$ for $12 \mathrm{~min}$ for injection in UFLC-MS/MS system.

UFLC-MS/MS analyses. A stock solution of $1000 \mu \mathrm{gmL}^{-1}$ of oleandrin was made in acetonitrile. Subsequent dilutions of the stock solution were also made in acetonitrile. Six-point matrix-matched calibration curves were prepared 0.005, 0.01, 0.025, 0.05, 0.075 and $0.10 \mu \mathrm{g} \mathrm{g}^{-1}$ by adding aliquots of oleandrin standard to dry, blank extracted samples.

Chromatographic analyses were performed using an ultra fast liquid chromatographic (UFLC) system (Shimadzu LC20ADXR, Shimadzu, Kyoto, Japan) equipped with a binary pump (Shimadzu LC20ADXR), an autosampler (Shimadzu SIL20ACXR), and a column oven (Shimadzu CTO20AC). Separations were achieved using an ODS column (Shimadzu Shimpack XR-ODSII column; $2.0 \times 100 \mathrm{~mm}$, $2.2 \mu \mathrm{m}$ particle size). Isocratic separation was carried out with a mobile phase consisting of $20 \%$ ammonium acetate $10 \mathrm{mmol} \mathrm{L}^{-1}$ (anhydrous ammonium acetate, purity $\geq 98 \%$; Vetec, Rio de Janeiro, Brazil) with A: $0.01 \%$ formic acid (PA, Tedia, Fairfield, USA), and B: $80 \%$ methanol (HPLC grade, Mallinckrodt, Phillipsburg, PA, USA) at a flow rate of $0.4 \mathrm{mLmin}^{-1}$, with total run time of $3 \mathrm{~min}$. An injection volume of $10 \mu \mathrm{L}$ was used and the column temperature was set to $60^{\circ} \mathrm{C}$.

Mass spectrometric analysis was carried out using a triple quadrupole mass spectrometer (5500 Triple Quad mass spectrometer,
Applied Biosystems/MDS SCIEX, Concord, Canada). The instrument was operated under electrospray ionization conditions (ESI) positive ion modes. Instrument settings, data acquisition, and processing were controlled by computer software (Analyst version 1.5.1, Applied Biosystems, Foster, CA, USA). Oleandrin was previously infused and optimized to the mass spectrometer. The source parameters optimized are as follows: ion spray voltage, $5.5 \mathrm{kV}$; curtain gas, 20psi; collision gas, $8 \mathrm{psi}$; nebulizer and auxiliary gas, $30 \mathrm{psi}$; ion source temperature, $500^{\circ} \mathrm{C}$. The MS/MS conditions for oleandrin were: precursor ion- $577.2[\mathrm{M}+\mathrm{H}]^{+}$; quantification and confirmation ions- 433.1 and 113.0; declustering potential (DP) 201 $\mathrm{V}$; whit energy potential (CE)- 13 and $21 \mathrm{~V}$; collision exit potential (CXP)- 38 and $10 \mathrm{~V}$ respectively.

The chromatograms of the evaluated compounds were used as standards for comparison with the test samples, and spiked samples at 0.01 and $0.1 \mu \mathrm{g} \mathrm{g}^{-1}$ were used with control of analytical quality.

Statistical analysis. Data are presented as mean \pm SEM (standard error of the mean). Statistical significance between groups were determined by $\mathrm{T}$ test. Significance level was set at $\mathrm{p}<0.05$. Data were analyzed using a computer software (GraphPad Prism v. 6.0, GraphPad, La Jolla, CA, USA).

\section{RESULTS}

Oleandrin was identified in the extract by retention time, mass weight and ion spectra and compared to the standard solution. Concentrations of oleandrin were determined by quantifying the peak area for the primary ion. HPLC-MS/MS detected oleandrin at retention time of $1.2 \mathrm{~min}$, with collision energy of 13 , temperature of $520^{\circ} \mathrm{C}$, cone exclusion potential of 28 and declustering potential of 201. Total run time was $3 \mathrm{~min}$ and detection limit $0.001 \mathrm{ngg}^{-1}$. Concentration levels found in hydroalcoholic extract of Nerium oleander corresponded to $1 \mathrm{mg}$ of extract containing $4.2 \mu \mathrm{g}$ of oleandrin with linear correlation $\mathrm{R}=0.99$ (Fig. 1 ).
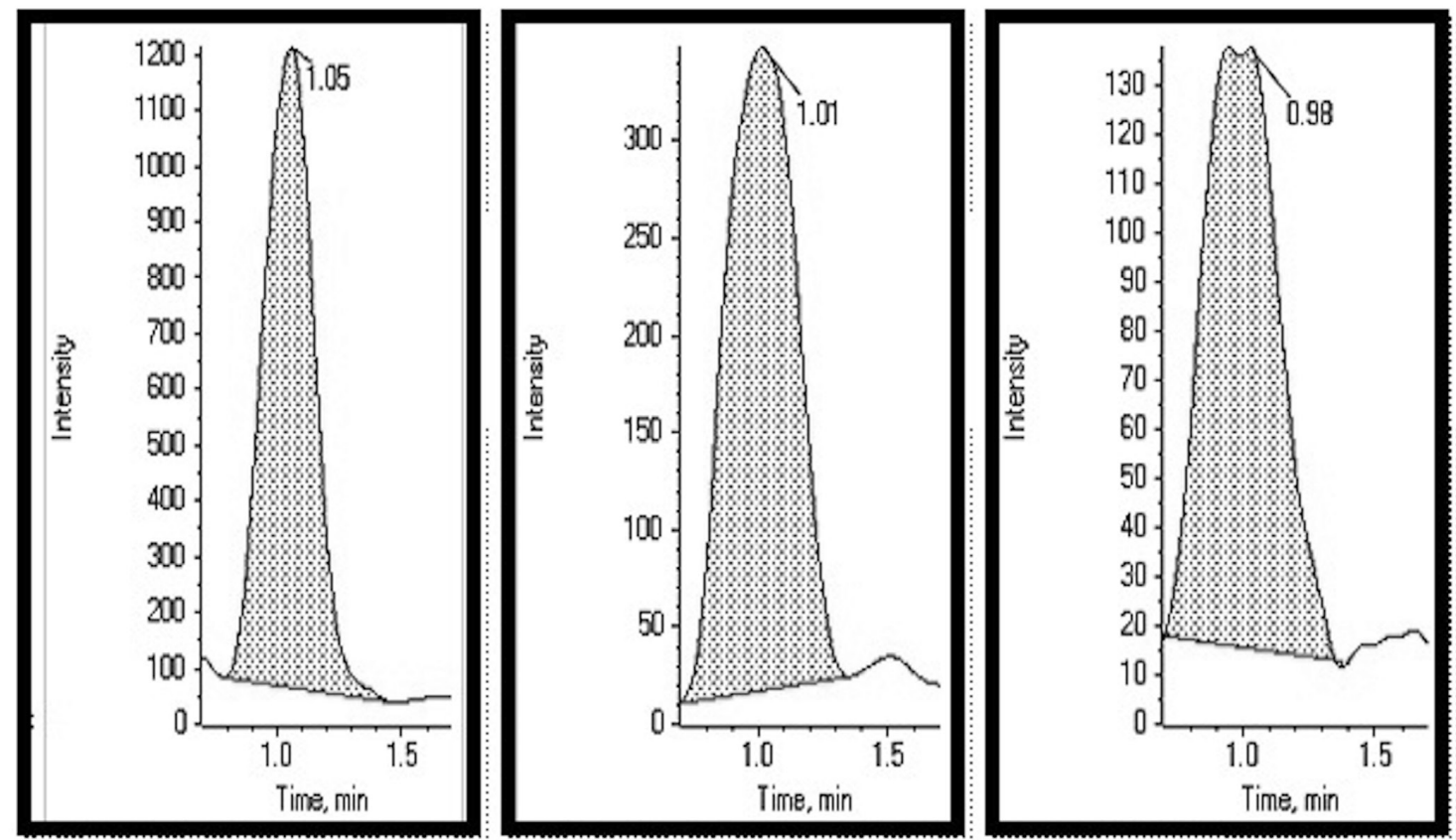

Fig.1. Chromatograms showing the retention time (in min) for oleandrin, obtained from total ion chromatogram from (A) control spiked sample of oleandrin. (B) Liver sample from guinea pig (Cavia porcellus) dosed with $300 \mathrm{mg} \mathrm{g}^{-1}$ of Nerium oleander extract. (C) Heart samples derived from the same individual. 
As shown in Figure 2, oleandrin tissue concentration was significantly greater in cerebral cortex of OLE 300 group $(p<0.05)$ than in OLE 150, although no significant differences in levels from heart, kidney and liver were observed. Comparison among tissues also showed no significant differences in oleandrin content, although increasing values were found: cerebral cortex, heart, kidney and liver.

\section{DISCUSSION}

This appears to be the first study that evaluates tissue oleandrin detection and distribution in guinea pigs poisoned by Nerium oleander. It presents a new extraction technique for oleandrin and a quick UFLC-MS identification and quantification method.

Several cases of $N$. oleander poisoning are reported as forensic cases, and the necropsy findings are usually mild and similar to those found in other poisonings, confounding the diagnosis. Plants that contain cardiac glycosides such as Thevetia peruviana and Digitalis lanata, and drug poisonings concerning digoxin and digitoxin intake, may cause the same clinical signs, cardiac arrhythmias and morphological lesions (Arao et al. 2002, Khan et al. 2010). In these cases, LC-MS/MS is the most recommended methodology to confirm the poisoning based on oleandrin content found in biological and plant tissues (Tor et al. 2005).
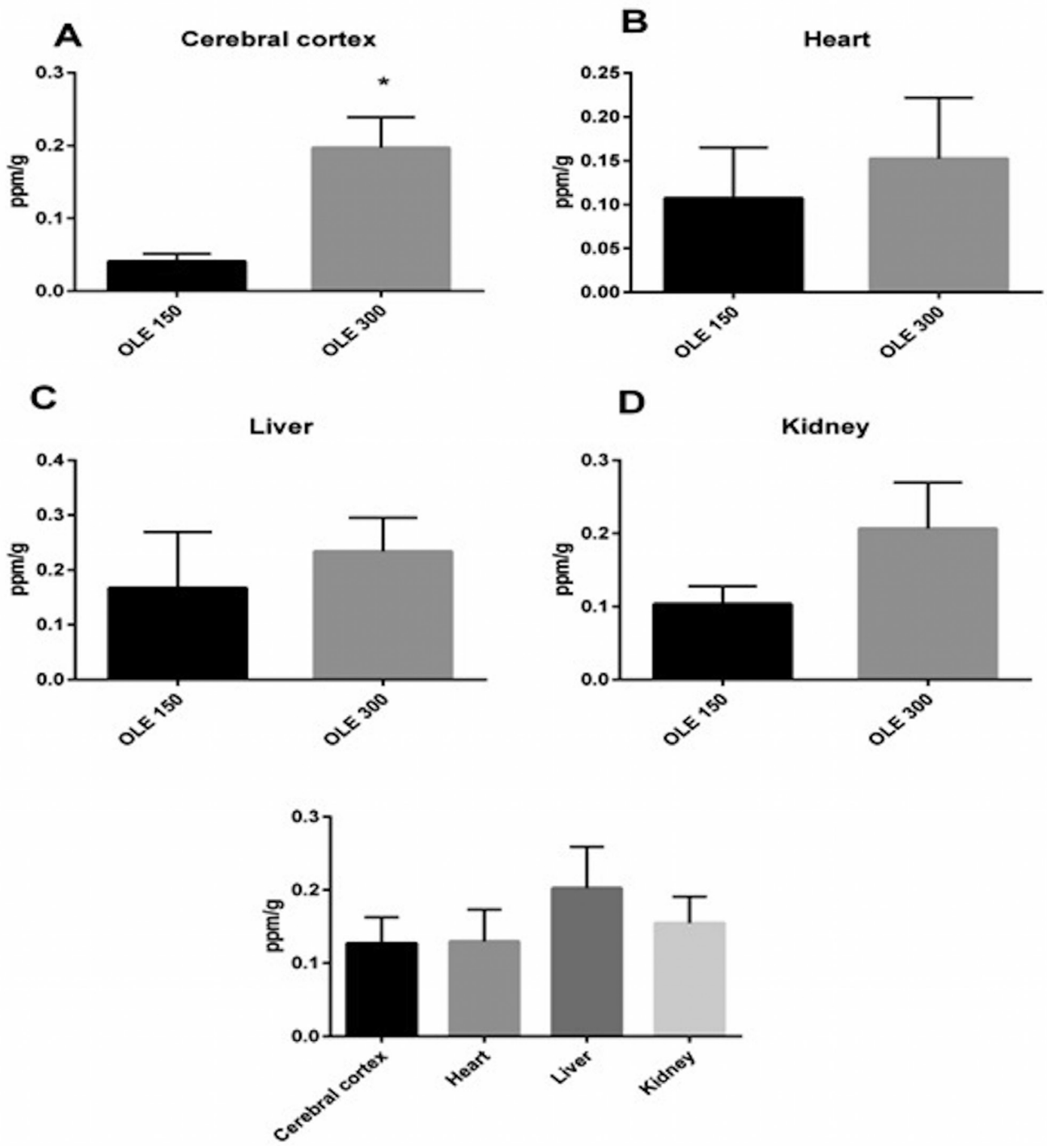

Fig.2. Mean and SEM of oleandrin concentration values (ppm) found in the organs of guinea pigs (Cavia porcellus) dosed with 150 and $300 \mathrm{mg} \mathrm{g}^{-1}$ de Nerium oleander detected by QuEChERS extraction and UFLC/MS (T test, p>0.05). (A) Values found in the cerebral cortex with significant rise in the group that received $300 \mathrm{mg} \mathrm{g}^{-1}$ of $N$. oleander extract. (B) Values found in the heart of both groups, showing no significant differences. (C) Values found in the liver of both groups also showing no significant differences. (D) Values found in the kidney of both groups without statistical differences. (E) Oleandrin concentrations compared between organs of OLE 150 and OLE 300 , showing no statistical difference. 
Oleandrin is main cardiac glycoside component in $N$. oleander, responsible for the clinical signs reported (Begum et al. 1999). The extract also contains flavonoids, tannin and other steroids not accessed in this evaluation. Oleandrin concentrations in plant extracts were previously studied using HPLC, obtaining median values of oleandrin of $4.89 \mathrm{mgg}^{-1}$, very similar to those found in the present study of $4.2 \mathrm{mgg}^{-1}$, confirming the cytotoxic potential of the extract (Pedroza et al. 2014). No difference has been reported in oleandrin content between plant varieties, pink, red and white flowers (Pedroza et al. 2014), justifying present use of the white variety. Leaves were used in the production of the extract due to its accessibility, quantity and harvesting potential (Barbosa et al. 2008).

Previous work has detected oleandrin in the liver, heart, urine, cerebrospinal liquid, muscle, stomach content and serum of poisoned individuals with simple extraction techniques and different ionization methods (Galey et al. 1996). In order to establish a rapid, simple and robust technique of extraction and analysis of oleandrin this study was performed. QuEChERS methodology is frequently used for multiresidues analysis of pesticides in vegetable origin samples and has been modified for different matrixes analysis (Oliveira et al. 2014). It removes many polar matrix contaminants, such as polar pigments, sugars and organic acids that disrupt chromatography readings. It establishes a simple, inexpensive and fast process for determination of different substances in various matrixes with minimal amounts of solvents with high quality results (Anastassiades et al. 2003). This is a new extraction method for oleandrin identification that provides cleaner samples to enhance reliability and promote faster readings.

In this study, oleandrin retention time was $1.2 \mathrm{~min}$ and total detection at medium 3 min. Faster identification is associated with newer technologies in chromatography and mass spectrometry, and is directly related to cleaner extraction technique derived from QuEChERS method. Mass spectrometry previous analyses were conducted with positive ion eletrospray ionization mode using a five point calibration curve and non-weighted linear regression. Retention time and spectrum of oleandrin in the heart muscle was identical to the liver (Tor et al. 2005). Detection limit determined by the same technique was $0.15 \mathrm{ngml}^{-1}$ in blood and cerebrospinal fluid samples (Arao et al. 2002).

Considering oleandrin toxicokinetics and metabolism, higher oleandrin levels are expected in the liver while kidney samples are expected to have lower levels ( $\mathrm{Ni}$ et al. 2002). However, oleandrin levels found in the present study were similar in liver and kidneys, showing both tissues are valuable samples for this toxicological analysis. Myocardial tissue also showed a considerable amount of the glycoside, which partially explains cardiac toxicity and potential use of oleandrin in heart insufficiency therapy (Alfonso et al. 1994, Barbosa et al. 2008, Gayathri et al. 2011) Important ECG alterations are associated with the ingestion of $N$. oleander leaves, flower and pods, in humans and animals (Hughes et al. 2002, Barbosa et al. 2008), and the content of oleandrin in heart is especially important to determine the severity of poisoning in clinical and forensic reports (Arao et al. 2002).

It has been established that oleandrin can rapidly accumulate in the brain tissue of rats, crossing the blood barrier and cause important neurological depressant activity in severe poisoning cases (Siddiqui et al. 1997, Ni et al. 2002). Clinical signs include disorientation, incoordination, convulsion and paresis (Siddiqui et al. 1997). In spite of these important signs, morphologic and histological alterations are usually nonspecific and include congestion and hemorrhage (Ada et al. 2001). Cerebral concentrations of oleandrin are dependent of other components of the extract, because these concentrations are higher after dosing the $N$. oleander extract than the pure oleandrin. However, the mechanism of this interaction remains to be clarified (Ni et al. 2002). This is the first report that oleandrin reaches the cerebrum in guinea pigs and represents an important finding, as the species is considered a model for cardiac toxicity evaluation and is significantly more sensitive to cardiac glycosides than rats and mice (Morissette et al. 2013).

\section{CONCLUSIONS}

The chemical study presents new conditions for diagnosis of Nerium oleander poisoning.

New techniques of extraction and oleandrin tissue identification provided detection time of only $1.2 \mathrm{~min}$ and total run of $3 \mathrm{~min}$.

The procedure simplifies workup steps, leading to a cleaner sample for UFLC-MS/MS.

This is also the first report of oleandrin tissue distribution in guinea pigs and the first to identify the glycoside in brain tissue of this species.

Acknowledgements.- The authors are thankful to Paula F. Milani for her help in anesthesia.

\section{REFERENCES}

Ada S.E., Al-Yahya M.A. \& Al-Farhan A.H. 2001. Acute toxicity of various oral doses of dried Nerium oleander leaves in sheep. Am. J. Clin. Med. 29(3/4):525 532. http://dx.doi.org/10.1142/S0192415X01000551. PMid:11789596.

Alfonso H.A., Sanchez L.M., Merino N. \& Gomez B.C. 1994. Intoxication due to Nerium oleander in geese. Vet. Hum. Toxicol. 36(1):47. PMid:8154101

Anastassiades M., Lehotay S.J., Stajnbaher D. \& Schenck F.J. 2003. Fast and easy multiresidue method employing acetonitrile extraction/partitioning and dispersive solid-phase extraction for the determination of pesticide residues in produce. J. AOAC Int. 86(2):412-431. PMid:12723926.

Arao T., Fuke C., Takaesu H., Nakamoto M., Morinaga Y. \& Miyazaki T. 2002 Simultaneous determination of cardenolides by sonic spray ionization liquid chromatography-ion trap mass spectrometry-a fatal case of oleander poisoning. J. Anal. Toxicol. 26(4):222-227. http://dx.doi.org/10.1093/ jat/26.4.222. PMid:12054363.

Bandara V., Weinstein S.A., White J. \& Eddleston M. 2010. A review of the natural history, toxinology, diagnosis and clinical management of Nerium oleander (common oleander) and Thevetia peruviana (yellow oleander) poisoning Toxicon 56(3):273-281. http://dx.doi.org/10.1016/j.toxicon.2010.03.026. PMid:20438743.

Barbosa R.R., Fontenele-Neto J.D. \& Soto-Blanco B. 2008. Toxicity in goats caused by oleander (Nerium oleander). Res. Vet. Sci. 85(2):279-281. http:// dx.doi.org/10.1016/j.rvsc.2007.10.004. PMid:18031775.

Begum S., Siddiqui B.S., Sultana R., Zia A. \& Suria A. 1999. Bio-active cardenolides from the leaves of Nerium oleander. Phytochemistry 50(3):435-438. http:// dx.doi.org/10.1016/S0031-9422(98)00523-8. PMid:9933955.

Blum L.M. \& Rieders F. 1987. Oleandrin distribution in a fatality from rectal and oral Nerium oleander extract administration. J. Anal. Toxicol. 11(5):219221. http://dx.doi.org/10.1093/jat/11.5.219. PMid:3682781. 
Calderón-Montaño J.M., Burgos-Morón E., Orta M.L., Mateos S. \& López-Lázaro M. 2013. A hydroalcoholic extract from the leaves of Nerium oleander inhibits glycolysis and induces selective killing of lung cancer cells. Planta Med. 79(12):1017-1023. http://dx.doi.org/10.1055/s-0032-1328715. PMid:23824549.

Caloni F., Cortinovis C., Rivolta M. \& Davanzo F. 2012. Animal poisoning in Italy: 10 years of epidemiological data from the poison control centre of Milan. Vet. Rec. 170(16):415-421. http://dx.doi.org/10.1136/vr.100210. PMid:22271801.

Dasgupta A. \& Datta P. 2004. Rapid detection of oleander poisoning by Dimension Vista digoxin assay (Flex Reagent Cartridge). Ther. Drug Monit. 26:658-663. http://dx.doi.org/10.1097/00007691-200412000-00012. PMid:15570191.

Dasgupta A., Klein K., Risin S.A. \& Actor J.K. 2011. Rapid detection of oleander poisoning by Dimension Vista digoxin assay (Flex Reagent Cartridge). J. Clin. Lab. Anal. 25(2):105-109. http://dx.doi.org/10.1002/jcla.20441. PMid:21438002.

Dorsey C.S. 1962. Plant dermatitis in California. Calif. Med. 96:412-413. PMid:13887444.

Galey F.D., Holstege D.M., Plumlee K.H., Tor E., Johnson B., Anderson M.L., Blanchard P.C. \& Brown F. 1996. Diagnosis of oleander poisoning in livestock. J. Vet. Diagn. Invest. 8(3):358-364. http://dx.doi.org/10.1177/104063879600800314. PMid:8844581.

Gayathri V., Ananthi S., Chandronitha C., Ramakrishnan G., Sundaram R.L. \& Vasanthi H.R. 2011. Cardioprotective effect of Nerium oleander flower against isoproterenol-induced myocardial oxidative stress in experimental rats. J. Cardiovasc. Pharmacol. Ther. 16(1):96-104. http:// dx.doi.org/10.1177/1074248410381759. PMid:21191138.

Hughes K.J., Dart A.J. \& Hodgson D.R. 2002. Suspected Nerium oleander (oleander) poisoning in a horse. Aust. Vet. J. 80(7):412-415. http://dx.doi. org/10.1111/j.1751-0813.2002.tb11000.x. PMid:12222602.

Karawya M.S., Balbaa S.I. \& Khayyal S.E. 1973. Estimation of cardenolides in Nerium oleander. Planta Med. 23(1):70-73. http://dx.doi. org/10.1055/s-0028-1099414. PMid:4734654.

Khan I., Kant C., Sanwaria A. \& Meena L. 2010. Acute cardiac toxicity of Nerium oleander/indicum poisoning (kaner) poisoning. Heart Views 11(3):115116. http://dx.doi.org/10.4103/1995-705X.76803. PMid:21577379.

Klinsunthorn N., Petsom A. \& Nhujak T. 2011. Determination of steroids adulterated in liquid herbal medicines using QuEChERS sample preparation and high-performance liquid chromatography. J. Pharm. Biomed. Anal. 55(5):1175-1178. http://dx.doi.org/10.1016/j.jpba.2011.03.046. PMid:21531110.

Langford S.D. \& Boor P.J. 1996. Oleander toxicity: examination of human and animal toxic exposures. Toxicology 109(1):1-13. http://dx.doi. org/10.1016/0300-483X(95)03296-R. PMid:8619248.
Mol H.G., Plaza-Bolaños P., Zomer P., Rijk T.C., Stolker A.A. \& Mulder P.P. 2008. Towards a generic extraction method for simultaneous determination of pesticides, mycotoxins, plant toxins, and veterinary drugs in feed and food matrixes. Anal. Chem. 80(24):9450-9459. http://dx.doi.org/10.1021/ ac801557f. PMid:19072261.

Morissette P., Nishida M., Trepakova E., Imredy J., Lagrutta A., Chaves A., Hoagland K., Hoe C.L., Zrada M., Travis J.J., Zingaro T.G., Gerenser P., Friedrichs G. \& Salata J. 2013. The anesthetized guinea pig: an effective early cardiovascular derisking and lead optimization model. J. Pharmacol. Toxicol. Methods 68(1):137-149. http://dx.doi.org/10.1016/j.vascn.2013.04.010. PMid:23649000.

Ni D., Madden T.L., Johansen M., Felix E., Ho D.H. \& Newman R.A. 2002. Murine pharmacokinetics and metabolism of oleandrin, a cytotoxic component of Nerium oleander. J. Exp. Ther. Oncol. 2(5):278-285. http://dx.doi. org/10.1046/j.1359-4117.2002.01052.x. PMid:12416031.

Oliveira F.S., Madureira F.D., Lopes R.P., Ferreira M.G., Soto-Blanco B. \& Melo M.M. 2014. Optimization of chromatographic conditions and comparison of extraction efficiencies of four different methods for determination and quantification of pesticide content in bovine milk by UFLC-MS/MS. Quím. Nova 37:1699-1706.

Pedroza H.P., Ferreira M.G., Carvalho J.G., Melo K.D.A., Keller K.M., Melo M.M. \& Soto-Blanco B. 2014. Concentrações de oleandrina nas folhas de Nerium oleander de diferentes cores de floração. Ciência Rural 45(5):864-866. http://dx.doi.org/10.1590/0103-8478cr20140885.

Shumaik G.M., Wu A.W. \& Ping A.C. 1988. Oleander poisoning: treatment with digoxin-specific Fab antibody fragments. Ann. Emerg. Med. 17(7):732-735. http://dx.doi.org/10.1016/S0196-0644(88)80625-5. PMid:3382077.

Siddiqui B.S., Sultana R., Begum S., Zia A. \& Suria A. 1997. Cardenolides from the methanolic extract of Nerium oleander leaves possessing central nervous system depressant activity in mice. J. Nat. Prod. 60(6):540-544. http://dx.doi.org/10.1021/np960679d. PMid:9214727.

Soto-Blanco B., Fontenele-Neto J.D., Silva D.M., Reis P.F.C.C. \& Nóbrega J.E.N. 2006. Acute cattle intoxication from Nerium oleander pods. Trop. Anim. Health Prod. 38(6):451-454. http://dx.doi.org/10.1007/s11250-0064400-x. PMid:17243471.

Tamura M., Uyama A. \& Mochizuki N. 2011. Development of a multi-mycotoxin analysis in beer-based drinks by a modified QuEChERS method and ultra-high-performance liquid chromatography coupled with tandem mass spectrometry. Anal. Sci. 27(6):629-635. http://dx.doi.org/10.2116/ analsci.27.629. PMid:21666361.

Tor E.R., Filigenzi M.S. \& Puschner B. 2005. Determination of oleandrin in tissues and biological fluids by liquid chromatography-electrospray tandem mass spectrometry. J. Agric. Food Chem. 53(11):4322-4325. http://dx.doi. org/10.1021/jf050201s. PMid:15913289. 